\title{
ANTITRUST CONSENT DECREES: HOW PROTECTIVE AN UMBRELLA?
}

\author{
SETH $M$, DABNEY†
}

BeCAUSE it can provide an "umbrella" which shields defendants in an antitrust action from future government attack, a consent decree may be more anxiously sought by defense counsel than dismissal of a case. Such were the views recently expressed by the majority of Representative Emanuel Celler's Antitrust Subcommittee in reporting their investigation of the consent decree program of the Department of Justice. They severely criticized the Attorney General for accepting a consent decree which in effect placed "the Government's imprimatur" upon conduct and relationships which had been attacked in the complaint. They emphatically preferred the dismissal of a case without prejudice to the entry of a consent decree which would "prevent a future attorney general . . . from bringing any effective antitrust action. ..." The report nevertheless recommended that the Department of Justice now take action to remedy what the Subcommittee majority regarded as the consent decree's inadequacies. ${ }^{1}$

Despite the ever-growing number of antitrust cases which have terminated in consent decrees and the importance of the consent decree as an instrument of law enforcement, considerable obscurity still surrounds the answers to important questions raised by the subcommittee's report. How protective an "umbrella" does an antitrust consent decree provide? Does such a decree lay to rest, with any measure of finality, further attacks upon the relationships or conduct alleged to be unlawful in the complaint? Does a consent decree providing only a part of the relief sought in a complaint effectively foreclose a subsequent proceeding which seeks to deal more stringently with the defendant?

Government counsel have two obvious ways to seek relief which, for one reason or another, has been passed over in a consent decree as ultimately negotiated. They can move in the initial proceeding to modify or to set aside the decree as entered. Or, choosing to ignore the prior proceeding, they can commence a new action and request relief similar to that originally sought.

† Member of the New York Bar.

1. Subcomim. No. 5, House Comar. on the Judictary, 86th Cong., 1st Sess., Report on the Consent Decree Program of the Dep't of Justice 84, 90, 291, 293-94 (Comm. Print 1959). The views of the Subcommittee majority in this respect reflected in large part the testimony of Victor H. Kramer, former Chief of the Antitrust Division's Section of Litigation, before the Subcommittee. See Hearings Before the Antitrust Subcommittee (Subcommittee No. 5) of the House Committee on the Judiciary, 85th Cong., 2d Sess., ser. 9, pt. 2, at 35\$2-83 (1958). 
As will be shown, the first of these approaches-modification of the decree -appears to present a difficult course indeed; and if this were the only method of penetrating the "umbrella," the protection afforded by a consent decree would appear substantial and well worth the efforts of defendant's counsel to achieve.

But the second approach, that of a new proceeding, is quite another matter. Here the "umbrella" develops apparent leaks which in particular cases can render its protection highly illusory. Of course, whatever its legal effect, in most instances counsels' bargain will prove a relatively durable one-for the very practical reason that any wholesale disregard of compromise arrangements would inevitably weaken or destroy the consent decree program as a method of law enforcement.

Uncertainties about the extent and durability of a consent decree's protection against future proceedings do, however, affect the course of negotiations. In bargaining for a settlement, government counsel are sensitive to the possibility of being barred from future action and to the criticisms which such a self-imposed paralysis might evoke. Defense counsel, on the other hand, strive for whatever advantages can be gained from such a bar. Neither side can be sure of the effect of its bargain in this respect. Both sides, therefore, may at times find advantages in negotiating the substantive provisions of a decree if the area of uncertainty surrounding the so-called protective umbrella is narrowed by specific terms of the decree itself.

\section{Modification of the Prior Decree}

Modification of a consent decree is typically contemplated by the document itself, which customarily provides that the court shall retain jurisdiction for the purpose of enabling any of the parties to apply at any time "for such further orders and directions as may be necessary or appropriate for the construction or carrying out of this Final Judgment, or the modification or termination of any of the provisions thereof. . .."2 Indeed, even without provisions expressly preserving jurisdiction, it is clear that the issuing court would inherently retain the power either to modify its decree to the extent that it deemed modification necessary and appropriate or, alternatively, to terminate the decree or some of its provisions. ${ }^{3}$

The efforts of government counsel, or, for that matter, defendant's counsel, to achieve modification or termination have, however, been met with a high degree of judicial reluctance to overturn the results of a bargain previously made by the parties and approved by the court. The language of Mr. Justice

2. The quoted language or its equivalent is "boiler plate" in most antitrust decrees, both litigated and consent, issued in recent years. In addition to providing for a general retention of jurisdiction, a number of consent decrees have included special modification provisions. See notes 7, 22 infra.

3. United States v. Swift \& Co., 286 U.S. 106, 114 (1932); FED. R. Civ. P. 60(b). 
Cardozo, speaking for the Supreme Court in United States v. Srerift \& Co., reflects the applicable rule, at least when a substantial modification is requested: "Nothing less than a clear showing of grievous wrong evoked by new and unforeseen conditions should lead us to change what was decreed after years of litigation with the consent of all concerned." 4 On the other hand, when the Court has regarded a modification as one which did not substantially change a decree, it has stated the rule less strictly: "The question is whether the change... [granted by the lower court] amounted to an abuse of this power to modify. We think that the test to be applied in answering this question is whether the change served to effectuate or to thwart the basic purpose of the original consent decree."

The basic issue in a proceeding to secure a substantial modification is whether conditions existing at the time modification is sought are different enough from those which formed the background for the original decree to justify the requested alteration. Because of this emphasis upon facts, a proceeding for substantial modification may well involve the introduction of voluminous evidence of an economic nature, and be in effect a full trial of limited issues. ${ }^{6}$ The Court has emphasized, however, that the inquiry in such a proceeding is not directed to reversing the original decree under the guise of a readjustment. It is not a re-examination of the merits of the injunction under the original facts, but solely a determination of whether the change in circumstances since the original decree is significant enough to warrant the modification sought ${ }^{7}$

Strict application of these principles has resulted in a record of reported decisions in which successful modification of a consent decree, when the change is opposed by the adverse party, is a rarity - whether modification be sought by plaintiff or defendant. Thus, the meat packers failed in 1930 to secure a release from stringent limitations imposed by a 1920 consent decree upon their dealing at retail in groceries and certain other products. ${ }^{8}$ The Department of Justice was unable, in 1923, to secure modification of a 1918 consent decree against International Harvester to require the breaking up of that company into three independent corporations-relief which had been

4. 286 U.S. 106,119 (1932).

5. Chrysler Corp. v. United States, 316 U.S. 556, 562 (1942).

6. Failure to provide a full hearing on a "substantial change" in a consent decree is reversible error. Hughes v. United States, 342 U.S. 353 (1952).

7. United States v. Swift \& Co., 286 U.S. 106, 119 (1932). In order to loosen the restrictions upon both plaintiff and defendant inherent in the "changed circumstances" rule, a number of consent decrees have contained, in addition to the general retentionof-jurisdiction clause, tailor-made provisions setting forth conditions, other than changed circumstances, upon which modification or termination may be had-either generally or with respect to particular items of the decree. A number of special provisions of this character are summarized in note 22 infra.

S. United States v. Swift \& Co., 286 U.S. 106 (1932). A renewal of efforts by the packers to modify this decree was begun in 1956 and is now pending. See 1958 Trade Cas. 73732 (D.D.C.). 
sought in the original complaint but abandoned in the consent settlement." Attempting unsuccessfully to lay the basis for more extensive substantive relief than was provided in its 1932 consent decree against RCA and others, the Government similarly failed in a 1942 effort to have the earlier decree vacated, an action which it maintained would be tantamount to dismissal of the case without prejudice. ${ }^{10}$ And despite their earlier success when a twoyear extension was involved, ${ }^{11}$ Justice Department attorneys were unable to secure a modification of the Ford automobile-finance decree which, in effect, would extend for ten years the time within which the Government was to obtain similar relief against a chief competitor, General Motors. ${ }^{12}$ Of more recent years, the Schine theatre interests (in 1954) were denied general relief from a five-year-old consent decree provision requiring that all theatres ordered to be sold be offered only as motion picture houses. ${ }^{13}$ And, in 1958, the Shuberts failed-despite the asserted difficulties of compliance-to obtain relief from the requirement of their 1956 consent decree that they dispose of certain theatres. ${ }^{14}$

The Justice Department has not been any more successful when it has sought an "interpretation" of a consent decree amounting, in the Court's view, to a substantial modification of its provisions. With respect to a decree providing that a motion-picture industry defendant might "either" sell certain stock "or" deposit it in a voting trust, the Court rebuffed a government attempt to have the voting-trust provisions construed as requiring sale of the stock by the voting trustee within a reasonable time. ${ }^{15}$ And the Liquid Car-

9. United States v. International Harvester Co., 274 U.S. 693 (1927).

10. United States v. Radio Corp. of America, 46 F. Supp. 654 (D. Del. 1942), appeal dismissed, 318 U.S. 796 (1943); see note 51 infra.

11. Chrysler Corp. v. United States, 316 U.S. 556 (1942); see text accompanying notes 17-19 infra.

12. Ford Motor Co. v. United States, 335 U.S. 303 (1948); see note 19 infra.

13. United States v. Schine Chain Theatres, Inc., 1954 Trade Cas. 69909 (W.D. N.Y.).

14. United States v. Shubert, 163 F. Supp. 123 (S.D.N.Y. 1958). The court's sixmonth extension of the time within which the theatres were to be sold was consented to and, in fact, suggested by the plaintiff.

15. Hughes v. United States, 342 U.S. 353 (1952). The Department of Justice has suggested that the statement of the Supreme Court in the Hughes case that it entertained "no doubt" of the "power" of the district court to order the divestiture of Hughes" stock after a proper hearing is indicative of a relaxation of the "changed circumstances" rule in connection with the modification of consent decrees at the request of the Government. Hearings Before the Antitrust Subcomnittee (Subcommittee No. 5) of the House Committee on the Judiciary, 85th Cong., 2d Sess., ser. 9, pt. 2, at 3748-49 (1958). This suggestion was adopted by the majority of the subcommittee in their report. See Surcomn. No. 5, House Comm. on the Judictary, 86rh Cong., 1st Sess., Report on the Consent Decree Program of the Dep't of Justice 5, 293 (Comm. Print 1959). Since the question has not been put to the Court since the Hughes decision, the Department may prove to be right, but it would appear to be relying upon a slender reed. The Court's statement was clearly directed to the question of the power of the district court to order divestiture as a form of relief against an individual rather than a corporation. The Court did not have before it the 
bonic consent decree, requiring the sale of plant property by a court-appointed trustee within a fixed time, a sale which subsequently proved impossible of accomplishment, did not admit of an "interpretation" to the effect that use of the plants by the defendant was thereafter enjoined. ${ }^{16}$

In contrast with this record of unsuccessful modification attempts, a few reported decisions have allowed modification in the face of opposition by one or more parties to the consent decree. The best known instance is the Chrysler Automobile Finance case. The Court there permitted a two-year extension of the time at which certain provisions of the consent decree were to lapse if the Government did not obtain similar relief, in a separate proceeding, against the General Motors Corporation. ${ }^{17}$ Characterizing its inquiry as a determination of "whether the change served to effectuate or to thwart the basic purpose of the original consent decree," 18 the Court noted Chrysler's failure to show that it would suffer a competitive disadvantage if the modification were allowed, particularly in view of the complete cessation of new-car and lighttruck manufacture wrought by the war. In sustaining the extension, however, it called attention to the lower court's invitation to Chrysler to come in at any time and make a showing of competitive disadvantage. ${ }^{19}$

Reference to the decree's objectives was also made in Continental Can, wherein a 1950 consent decree was reformed in 1953. The requirement that can-closing equipment be rented at "compensatory" rates was, upon an appli-

question of what circumstances might be developed at the hearing which would justify the use by the district court of its "power" to order this relief and thereby substantially modify the decree.

16. Liquid Carbonic Corp. v. United States, 350 U.S. 869 (1955), reversing 123 F. Supp. 653 and 121 F. Supp. 141 (E.D.N.Y. 1954).

17. Chrysler Corp. v. United States, 316 U.S. 556 (1942).

18. Id. at 562. The "purpose" test, applied to consent decrees, presents serious practical difficulties stemming from the usual absence of any record (other than the complaint and answers, which normally are contradictory), to show what ends the decree, or any of its provisions, was designed to effectuate. Only rarely does the consent decree itself contain a recital of objectives or purposes. For examples of this latter type of decree, see United States v. Continental Can Co., 1950-51 Trade Cas. 63976 (N.D. Cal. 1950) (art. III(10)), discussed in note 20 infra; United States v. Columbia Artists Management Inc., 1955 Trade Cas. 70830 (S.D.N.Y.) (to facilitate and increase booking of independently managed artists and to promote competition among defendants and between independents and defendants in the management of artists).

19. 316 U.S. at 564. The Chrysler decision was distinguished in the subsequent Ford case in 1948, which involved a parallel decree. Ford Motor Co. v. United States, 335 U.S. 303 (1948). The Court in the later case pointed out that the two-year extension permitted in Chrysler had now stretched to ten; that the wartime cessation of car manufacture was no longer in effect, and that a showing of competitive disadvantage was therefore no longer necessary. The crucial fact, it said, was not the degree of disadvantage but the persistence of an inequality against which protection had been secured in a wellunderstood and carefully drawn decree. Chrysler has been rarely cited, and then usually only for general propositions in conjunction with Swift, International Harvester, and other early Supreme Court modification decisions. 
cation of the defendant opposed by the plaintiff, modified to require only "reasonable" rentals. ${ }^{20}$ The court emphasized that adherence to the decree's original terms would necessitate rental increases of as much as 108 per cent and would work an economic hardship on the small canner by, in effect, forcing purchase of the equipment. The decree, it held, was never designed to operate in so compulsive or arbitrary a fashion.

The reported cases ${ }^{21}$ thus indicate rather strongly that, absent special language establishing more liberal standards than are implicit in the usual retention-of-jurisdiction clause, ${ }^{22}$ neither plaintiff nor defendant in an antitrust

20. United States v. Continental Can Co., 128 F. Supp. 932 (N.D. Cal. 1955). The original provision required that "reasonable" rentals be maintained until 1954 and that, thereafter, rentals take into account not less than the aggregate of expenses incurred, including depreciation, a reasonable return on investment, and the cost of providing services in connection with the leasing of machines and equipment. In any proceeding to enforce this provision the burden was placed upon defendant to establish that its rentals were in compliance. United States v. Continental Can Co., 1950-51 Trade Cas. 63976 (N.D. Cal. 1950) (art. III(10)). The decree also contained an announcement of its "express purpose" as being "to assure to those interested in owning container closing machines ... the opportunity to purchase ... and ... for defendant to adopt a policy of affording to all those desiring such machines ... every available economic incentive to purchase ...."Id. (art. III(1)). In modifying the decree, the court required, inter alia, that rentals not be set so as to make leasing more advantageous than purchasing.

21. Those noted in the text, Chrysler and Continental Can, together with American Press Ass'n v. United States, 245 Fed. 91 (7th Cir. 1917) (modification granted to permit sale of assets to a competitor by defendant unable to continue operations profitably), are the only reported cases coming to the author's attention in which, absent a special modification clause or the consent of the adverse party, an antitrust consent decree has been altered after entry.

22. See note 7 supra. Special modification provisions have been included in consent decrees for a considerable number of years and have been quite varied. Early examples are contained in the National Cash Register consent decree of 1916, referred to in Allen -Calculators, Inc. v. National Cash Register Co., 322 U.S. 137, 138-39 (1944), and in the International Harvester decree of 1918 cited in United States v. International Harvester Co., 274 U.S. 693 (1927).

For more recent cases, see United States v. American Smelting \& Ref. Co., 1957 Trade Cas. 73398 (S.D.N.Y.) (defendant may petition for relief from certain provisions after ten years upon showing that action contemplated will not substantially lessen competition or tend to create a monopoly); United States v. National Cranberry Ass'n, 1957 Trade Cas. 73442 (D. Mass.) (plaintiff after five years may apply for such further relief as it then deems necessary or appropriate; if it seeks divestiture, defendants shall have burden of establishing why this relief should not be ordered; defendants may seekmodification of any provision in conflict with a marketing agreement with, or an order of, the Secretary of Agriculture, without showing any other change in circumstances); United States v. Wolf, 1957 Trade Cas. 73612 (E.D. La.) (defendant may seek modifcation or termination of any provision which it can establish is causing undue hardship because of federal regulations or rulings governing purchase and sale of cotton); United States v. Meredith Publishing Co., 1956 Trade Cas. 71549 (S.D.N.Y.) (defendant after one year may obtain relief from injunction against certain resale price maintenance contracts if court shall then determine that the contracts do not violate federal law); United States v. Shubert, 1956 Trade Cas. 71233 (S.D.N.Y.) (if plaintiff, during periods of 
case can realistically expect to achieve the unilateral modification of a consent decree. Modification depends either upon a substantial and unforeseen change in conditions since the date of the original decree, or upon the fact that the change sought is relatively insubstantial and within the agreed-upon purpose of the original decree. The record of meager success in the modification cases, however, stands in rather sharp contrast to the possibilities open to plaintiff's counsel by the institution of a new and separate proceeding.

\section{Protection Against a New Proceeding}

The basic problem in this connection is the extent to which the doctrine of res judicata applies in a civil antitrust action to foreclose a second attempt by government counsel to secure relief which, for one reason or another, they saw fit to do without in a prior proceeding. The observation has been made that, in a surprising number of the antitrust cases in which a plea of res judicata might have been anticipated, it was never pressed. ${ }^{23}$ The disposition of such pleas as have been made over the years, however, helps to explain the apparent reticence of counsel to rest upon that defense. Although antitrust cases in which a plea of res judicata has been the subject of a reported opinion are relatively few, it is still significant that the plea has successfully barred a subsequent proceeding in only two instances. In each, the court relied upon

time which may be extended by the court, shows, in a proceeding devoid of any burden of proof, that independent theatres have not been given opportunity to contract for Theatre Guild attractions, court may order defendant to refrain from presenting such attractions); United States v. Hilton Hotels Corp., 1956 Trade Cas. 7.117.1 (N.D. I11.) (defendant, without proving changed circumstances, may apply for permission to acquire hotels otherwise prohibited by decree upon a satisfactory showing that a proposed acquisition will not substantially lessen competition or tend to create a monopoly). Still other variations of special modification clauses may be found in United States v. Kosher Butchers' Ass'n, 1955 Trade Cas. 70206 (S.D. Cal.) ; United States v. Columbia Artists Management Inc., 1955 Trade Cas. 70830 (S.D.N.Y.); United States v. Minute Maid Corp., 1955 Trade Cas. 70673 (S.D. Fla.); United States v. Twentieth Century-Fox Film Corp., 1955 Trade Cas. 70684 (S.D. Cal.) ; United States v. Continental Can Co., 1950-51 Trade Cas. 63976 (N.D. Cal. 1950) ; United States v. International Nickel Co. of Canada, 1948-49 Trade Cas. 62634 (S.D.N.Y. 1948); United States v. Paramount Pictures, Inc., 1940-43 Trade Cas. 288 (S.D.N.Y. 1940).

A subsequent application for modification under a clause of the type here noted is described in Allen Calculators, Inc. v. National Cash Register Co., supra. There, an acquisition was permitted over government opposition under a clause of a consent decree requiring the court to determine whether an acquisition otherwise prohibited (a) would supplement the defendant's facilities, (b) was sought for that purpose, and (c) would not substantially lessen competition. See also United States v. International Harvester Co., supra at 697, where the plaintiff failed to secure additional relief under a clause permitting reopening after a lapse of time to attain the "object" of restoring "competitive conditions in the ... interstate business in harvesting machines and other agricultural implements."

23. Black, Res Judicata and Conspiracy Cases Under the Sherman Act, 30 KY. L.J. 255, 256 (1942). 
the fact that the case involved a private plaintiff. ${ }^{24}$ The amorphous and slippery nature of an antitrust cause of action, the variety of proceedings open to government counsel, the changes wrought by the passage of time upon the conduct and composition of affairs that are vulnerable to attack as antitrust violations, and the obvious reluctance of the courts to preclude the enforcement of the antitrust laws-all combine to limit and render uncertain the protection which a prior decree may afford against subsequent attack.

The doctrinal formulation of res judicata principles in this area is simple enough in itself. When the prior decree has been consented to by the parties without actual litigation of any issue, application of the bar ultimately depends upon a determination by the court that plaintiff's second proceeding presents the "same cause of action" that was involved in the earlier case. ${ }^{25}$ A subse-

24. F. L. Mendez \& Co. v. General Motors Corp., 161 F.2d 695 (7th Cir.), cert. denied, 332 U.S. 810 (1947) ; Williamson v. Columbia Gas \& Elec. Corp., 186 F.2d 464 (3d Cir. 1950), cert. denied, 341 U.S. 921 (1951). The courts held that decisions adverse to the plaintiffs in previous treble-damage actions based on $\S \S 1$ and 2 of the Sherman Act barred subsequent proceedings in which substantially the same circumstances were cited as violations of $\S \S 3$ and 7 of the Clayton Act. The Supreme Court had earlier reached the opposite result in a case involving $\S 3$ of the Clayton Act in which the United States was the plaintiff, United Shoe Mach. Corp. v. United States, 258 U.S. 451 (1922). This decision was distinguished by both the Mendez and Williamson courts on the basis of the difference in the identity of the plaintiff.

25. The classical statement of the principles of res judicata is contained in Cromwell v. County of Sac, 94 U.S. 351, 352-53 (1876) :

[Where the prior judgment involves] the same claim or demand . . . the judgment, if rendered upon the merits, constitutes an absolute bar to a subsequent action. It is a finality as to the claim or demand in controversy, concluding parties and those in privity with them, not only as to every matter which was offered and received to sustain or defeat the claim or demand, but as to any other admissible matter which might have been offered for that purpose. . . The language, therefore, which is so often used, that a judgment estops not only as to every ground of recovery or defence actually presented in the action, but also as to every ground which might have been presented, is strictly accurate, when applied to the demand or claim in controversy. Such demand or claim, having passed into judgment, cannot again be brought into litigation between the parties in proceedings at law upon any ground whatever.

But where the second action between the same parties is upon a different claim or demand, the judgment in the prior action operates as an estoppel only as to those matters in issue or points controverted, upon the determination of which the finding or verdict was rendered. In all cases, therefore, where it is sought to apply the estoppel of a judgment rendered upon one cause of action to matters arising in a suit upon a different cause of action, the inquiry must always be as to the point or question actually litigated and determined in the original action, not what might have been thus litigated and determined. Only upon such matters is the judgment conclusive in another action.

See also Lawlor v. National Screen Serv. Corp., 349 U.S. 322 (1955); United States v. Moser, 266 U.S. 236, 241. (1924) ; Restatenent, Judgments $\$ \$ 45,46$ (1942). Compare the language in Aluminum Co. of America v. United States, 302 U.S. 230, 232 (1937): the two suits must be "substantially identical in subject matter and issues." 
quent antitrust proceeding held to constitute a different cause of action is not foreclosed by a prior consent decree even when the second suit raises an issue or issues which formed part of the original proceedings, since those issues have never been actually litigated. ${ }^{20}$ Inquiry is thus directed only to whether the same, or different, causes of action underlie the two proceedings. ${ }^{27}$ Unlike the many suits-such as an action on a promissory note, for breach of contract, or for negligence-in which the same-cause-of-action test is relatively easy to apply, in an antitrust case it poses difficult problems of analysis.

\section{The Passage of Time and Intervening Changes}

An obvious basis for distinguishing the subsequent action from an earlier one is provided when the conduct later complained of occurred subsequent to the earlier proceeding. Such conduct may well be held to create a new cause of action, even when it is, in essence, a continuation of conduct which, as of an earlier date, was attacked in the prior proceeding. Thus, the time element was accorded a position of prominence in Lawlor $v$. National Screen Service Corp. ${ }^{28}$ one of the few cases in which res judicata in the antitrust context has come before the Supreme Court. There, seven years after an earlier private treble damage action had been dismissed with prejudice before trial pursuant to a consent settlement, the plaintiff brought suit against the former defendants, together with others who, the plaintiff alleged, had since joined the conspiracy charged in the original complaint. Plaintiff now sought damages for activities resulting from operation of the conspiracy in the period subsequent to the earlier suit. Although the court of appeals found-and the Supreme Court did not dispute-that the later suit involved "essentially the same course of wrongful conduct," the Supreme Court unanimously reversed a holding that the doctrine of res judicata barred the second proceeding. The

26. Lawlor v. National Screen Serv. Corp., 349 U.S. 322, 326 (1955). Since no issues would have been tried in the proceeding terminated on consent, there would appear no possible basis upon which to apply the rule of "collateral estoppel" as that rule is phrased in Cromwell v. County of Sac, supra note 25, or RestateMent, JudGMENTs $\$ \S 68,70$ (1942). When, however, the consent decree orders an actual disposition of property, it may well be that, even in a different proceeding, the merits of that particular disposition, as distinguished from the underlying issue of law, may be barred to further litigation between the parties. Compare Standard Oil Co. v. Clark, 163 F.2d 917 (2d Cir. 1947), cert. denied, 333 U.S. 873 (1948), modifying 64 F. Supp. 656 (S.D.N.Y. 1945) ; RESTATENENT, JUDGMENTS $§ 75$, comment $c$ (1942).

27. The estoppel created when the same cause of action is determined to exist has been described in broad terms:

When the second suit is between the same parties, or their privies, and upon the same cause of action as the first, the judgment or decree in the first is conclusive upon all the parties and their privies in the second suit, not only as to every question and issue which was, but also upon every question and issue, claim, or defense which might have been presented in the first suit.

Miller v. Belvy Oil Co., 248 Fed. 83, 86 (8th Cir. 1917).

28. 349 U.S. 322 (1955). 
same course of wrongful conduct, it theorized, might give rise to more than one cause of action. Noting the lapse of time, it ruled that, whether the defendant's conduct "be regarded as a series of individual torts or as one continuing tort," the earlier judgment, though precluding recovery on claims arising prior to its entry, did not constitute a bar to the subsequent suit. Nor was this conclusion affected by the fact that in the earlier suit the plaintiff had sought not only money damages but injunctive relief against continuation of the alleged conspiracy. The two suits, the Court held, did not involve the same cause of action.

Even if continuation of the same conduct were held to give rise to the same cause of action, the defense of res judicata would still be of limited application because business situations do not often remain static over a period of years. Changes in the actors and in the course of conduct complained of quite naturally tend to evolve during the lapse of time between a first and second antitrust proceeding. Such changes-new practices, new participants, an increase in the scope of a monopoly position or the expiration of significant patents-all interrupt the continuity of conduct and have been influential factors in decisions that a prior proceeding should not bar a subsequent action. ${ }^{29}$ The longer the period of time, the more such changes may be found. As a practical matter, therefore, only a rare case would present solely the element of time lapse.

Although the passage of time can create a new cause of action, the existence of an earlier decree is not without practical significance. Plaintiff may not be barred from instituting a second proceeding, but he may well find the court, during the trial in that proceeding, unwilling to admit proof which extends back into the period covered by the earlier case. ${ }^{30}$ In particular situations, such a limitation can be of considerable importance.

\section{The Government's Choice of Proceeding}

Much the same circumstances may constitute a violation of more than one provision of the antitrust laws. The resulting alternate remedies and proceedings available in antitrust matters present another avenue of approach for government counsel who seek to avoid the results of an earlier decree.

Typically, a complaint prepared by the Department of Justice will allege in general fashion the existence of a conspiracy among the defendants producing a restraint of trade violative of section 1 of the Sherman Act. This general allegation is ordinarily followed by an enumeration of more or less specifically described activities or relationships which, it is averred, have come

29. See Lawlor v. National Screen Serv. Corp., 349 U.S. 322 (1955); Aluminum Co. of America v. United States, 302 U.S. 230, affirming 20 F. Supp. 608 (W.D. Pa. 1937) ; cf. United States v. General Elec. Co., 82 F. Supp. 753 (D.N.J. 1949) (involving an earlier litigated decree).

30. Kramer, Modification of Consent Decrees: A Proposal to the Antitrust Division, 56 MiCH. L. Rev. 1051, 1062 n.50 (1958). 
about pursuant to, and in implementation of, the general conspiracy. Frequently, the relief demanded is directed primarily at one or more of these specific activities or relationships. The judgment actually secured in such a case, particularly when a consent decree is the instrument of redress, often fails to deal with all of the individually described conspiratorial acts. ${ }^{31}$

But such a final judgment may not set the matter to rest. Particular acts or relationships which were passed over in the prior decree may themselves form the basis of an antitrust cause of action, a basis wholly apart from the general conspiracy of which they were originally alleged to be elements. ${ }^{32}$ FTC v. Motion Picture Advertising Service Co. ${ }^{33}$ provides a good example. A prior complaint under section 5 of the Federal Trade Commission Act had charged that a conspiracy existed among the defendant and others to use certain exclusive dealing contracts in the course of their business. An order to cease and desist from the unlawful combination had been entered in the prior proceeding after trial. ${ }^{34}$ Apparently, however, this relief failed to achieve the results envisioned by the Commission, and its indefatigable staff thereupon initiated a proceeding under section 3 of the Clayton Act, charging that the exclusive-dealing contracts themselves were invalid even in the absence of conspiracy. A new order to cease and desist resulted. To the defendants' contention that the second proceeding was barred by the first, Justice Douglas simply replied that the former proceeding involved a charge of conspiracy, not the legality of the contracts themselves.

31. Occasionally, the decree will specifically recite that nothing therein is to be construed as prohibiting certain enumerated activities or types of conduct. These frequently include activities which otherwise would have been encompassed by broad language used in the complaint, if not in the decree itself. See, e.g., United States v. National Container Ass'n, 1940-43 Trade Cas. 84 (S.D.N.Y. 1940), and the related Department of Justice press release, dated December 16, 1940, to the effect that the exception from a decree of enumerated activities does not signify that these activities are authorized, but rather that they remain as vulnerable to attack under the antitrust laws as if the decree had not been entered. Other examples include: United States v. American Ass'n of Advertising Agencies, Inc., 1956 Trade Cas. 71167 (S.D.N.Y.) ; United States v. Textile Refinishers Ass'n, Inc., 1955 Trade Cas. 70651 (S.D.N.Y.) ; United States v. General Motors Corp., 1952-53 Trade Cas. 67776 (N.D. Ill. 1952); United States v. Institute of Carpet Mfrs. of America, Inc., 1940-43 Trade Cas. 384 (S.D.N.Y. 1941). See Isenbergh \& Rubin, Antitrust Enforcement Through Consent Decrees, 53 HARv. L. Rev. 386, 392-95 (1940).

32. A number of consent decrees in which alleged conspiracies under $\$ 1$ of the Sherman Act have been enjoined have dealt specifically with the possibility of a subsequent attack for monopolization in violation of $\S 2$ of the act. They have customarily provided that entry of the decree is not a bar to subsequent prosecution of such a complaint. Examples of such decrees are contained in United States v. General Mills, Inc., 1955 Trade Cas. 70619 (E.D. Mich.) ; United States v. American Smelting \& Ref. Co., 1957 Trade Cas. 73398 (S.D.N.Y.). The statement in text is concerned with the situation in the absence of special provisions and with respect not only to $\S 2$ of the Sherman Act but to other antitrust provisions as well.

33. 344 U.S. 392 (1953).

34. Screen Broadcast Corp., 36 F.T.C. 957 (1943). 
Finally, respondent urges that the sole issue raised in the Commission's complaint had been adjudicated in a former proceeding instituted by the Commission which resulted in a cease and desist order .... But that was a proceeding to put an end to a conspiracy between respondent and other distributors involving the use of these exclusive agreements. The present proceeding charges no conspiracy; it is directed against individual acts of respondent. The plea of res judicata is therefore not available since the issues litigated and determined in the present case are not the same as those in the earlier one. ${ }^{35}$

This result might well have been anticipated in view of the Court's earlier decision in United Shoe Machinery Corp. v. United States. ${ }^{36}$ There, the first complaint, which had been dismissed after trial, had alleged as violations of sections 1 and 2 of the Sherman Act a consolidation of independent companies and a system of shoe machinery leases with tying clauses. ${ }^{37}$ Within eight months of the dismissal, the Department of Justice had filed a new complaint -this time under section 3 of the Clayton Act-attacking the same restrictive lease clauses cited in the original allegations. The defendant, of course, pleaded the dismissal of the prior proceeding as a bar to the later suit. Relying upon the different statutory bases for the two actions, the Supreme Court overruled the plea.

The Sherman Act and the Clayton Act provide different tests of liability. . . . Under the Sherman Act, as interpreted by this court before the passage of the Clayton Act, contracts were prohibited which unduly restrain the natural flow of interstate commerce, or which materially interrupt the free exercise of competition in the channels of interstate trade. In the second section monopolization or attempts to monopolize interstate trade were condemned. The Clayton Act (3) prohibits contracts of sale, or leases made upon the condition, agreement or understanding that the purchaser or lessee shall not deal in or use the goods of a competitor of the seller or lessor where the effect of such lease, sale, or contract, or such condition, agreement or understanding "may" be to substantially lessen competition or tend to create monopoly. The cause of action is therefore not the same. ${ }^{38}$

The significance of section 7 of the Clayton Act as a route to a second attack upon relationships previously assailed as a Sherman Act conspiracy must also be considered-particularly when an acquisition by the defendants was specified in the original complaint as one of the steps in the alleged conspiracy, but the relationship was left undisturbed by a consent decree. The

35. $344 U_{2} S$. at $397-98$.

36. 258 U.S. 451 (1922).

37. United States v. United Shoe Mach. Co., 247 U.S. 32 (1918). The action commenced on December 12,1911, and the lower court dismissed the petition on March 18, 1915. Section 3 of the Clayton Act became law in October, 1914. The second proceeding under that section was begun on October 18, 1915, even before the Supreme Court's decision in the first case.

38. 258 U.S. at $459-60$. 
possibilities of using section 7 to reopen the case in such circumstances were substantially increased by the decision in the $d u$ Pont-General Motors case, ${ }^{39}$ which interpreted the section as applying to acquisitions which may have occurred many years ago. ${ }^{40}$

The res judicata implications of parallel action by the Department of Justice and the Federal Trade Commission under different sections of the antitrust law have not yet received careful judicial scrutiny. In the past, those agencies have not hesitated to proceed separately against the same situation. ${ }^{41}$ While this practice has been deprecated ${ }^{42}$ and both agencies have in recent years sought to effect the necessary liaison to avoid rivalry in acquiring jurisdiction, ${ }^{43}$ the attitude of the courts in Motion Picture Advertising Service and United Shoe Machinery may suggest that neither agency is barred from initiating a subsequent proceeding if it is dissatisfied with the results achieved, or the results it thinks will be achieved, by the other.

The rather rigid adherence to form which characterizes the treatment of res judicata problems in the antitrust field appears to reflect a judicial attitude

39. United States v. E. I. duPont de Nemours \& Co., 353 U.S. 586 (1957).

40. Id. at 596-99. Thus, theoretically at least, only acquisitions occurring prior to the existence of $\S 7$ of the Clayton Act are immune from this type of attack.

41. Compare FTC v. Cement Institute, 333 U.S. 683 (1948), with United States v. Cement Institute, Civil No. 1291, D. Colo. (filed 1945, dismissed 1953). The latter proceeding was begun by the Department of Justice on June 2S, 1945 after the FTC's order to cease and desist had been entered and while respondent's motion to set it aside was pending in the court of appeals. Apart from their different statutory bases (the Federal Trade Commission Act and Sherman Act, respectively), the two proceedings were substantially identical. A motion in the Sherman Act case to dismiss for mootness, made after the Supreme Court rendered its decision in the FTC suit, failed. United States v. Cement Institute, 1948-49 Trade Cas. 63341 (D. Colo. 1949). Ultimately, the Department of Justice was persuaded to dismiss the second action in 1953, five years after the Supreme Court had sustained the order issued by the FTC.

The Supreme Court's opinion in the Cement Institute case approaches the problem of a possible bar resulting from prior action by a different agency under a different section of the law. The defendants in this case placed heavy reliance upon the Court's earlier decision in Cement Mfrs. Protective Ass'n v. United States, 268 U.S. 588 (1925), an action by the Department of Justice for alleged violations of $\S 1$ of the Sherman Act. The Court ruled that the earlier case had "little relevance, if any at all, to the issues in the case at bar." 333 U.S. at 706. After distinguishing the two cases on their facts, the Court went on to point out that: "these marked differences between what a court must decide in a Sherman Act proceeding and the duty of the Commission in determining whether conduct is to be classified as an unfair method of competition are enough in and of themselves to make the Old Cement decision wholly inapplicable ...." Id. at 709 . The decision of the district court on the mootness motion in the second Department of Justice case was to much the same effect.

42. "It is basic to all relations between the two agencies that both should never for any reason, including differences in views as to the law or the facts, proceed against the same parties for the same offense growing out of the same factual situation." ATr'Y GEN. Nat'l Comm. Antitrust Rep. 377 (1.955).

43. Id. at 376 . 
that restrictions upon enforcement of the antitrust laws should be minimized, at least when the United States or a Government agency is vindicating the public interest as the party plaintiff. Significantly, when private actions have been concerned, at least two courts of appeals have explicitly blocked the road to a second proceeding on the same general facts but under a different provision of the antitrust laws. ${ }^{44}$ Both courts adopted essentially the same reasoning : a private plaintiff may only recover for damage to or deprivation of a property right; whether he alleges violation of one statutory proscription or another, his cause of action for injury to his business or property is the same; suits by the Government, on the other hand, are to correct or punish separate offenses, violations of a "distinct and separate statutory duty" $; 4$ they protect "public rather than private interests." 46 These decisions, beside reflecting a judicial distaste for the private antitrust plaintiff, rather clearly affirm the right of the Government to tread a path barred to the private litigant.

It should be pointed out that in most of the reported decisions in which a new proceeding has been attempted after entry of an earlier decree, the prior decree has been entered after litigation rather than by consent of the parties. Lawlor, involving a private plaintiff, and Aluminum, ${ }^{47}$ where more than twenty-five years elapsed between the first and second proceedings, were the only cases in which the prior judgment was rendered on consent of the parties. That fact, however, does not present a likely basis for a distinction, for the elements which differentiate one cause of action from another can hardly be said to include the manner in which a prior proceeding was terminated.

The umbrella of protection afforded by consent judgments, viewed strictly as a matter of legal right, would thus appear to have a number of substantial holes in many typical cases. Again, this does not mean that, as a practical matter, the defendant who accedes to a consent decree may not in fact realize a substantial measure of protection from his bargain. Certainly, it is most unlikely that, after the intense and difficult negotiations which produce a consent settlement, government counsel will tomorrow begin a new and different proceeding to attack the very situation which yesterday they were willing to include in their agreement. No course of conduct would be more likely to wreck

44. Williamson v. Columbia Gas \& Elec. Corp., 186 F.2d 464 (3d Cir. 1950), cert. denied, 341 U.S. 921 (1951) ; F. L. Mendez \& Co. v. General Motors Corp., 161 F.2d 695 (7th Cir.), cert. denied, 332 U.S. 810 (1947).

45. F. L. Mendez \& Co. v. General Motors Corp., supra note 44, at 698.

46. Williamson v. Columbia Gas \& Elec. Corp., 186 F.2d 464, at 468 (3d Cir. 1950), cert. denied, 341 U.S. 921 (1951).

47. Aluminum Co. of America v. United States, 302 U.S. 230 (1937).

48. When the prior proceeding has been terminated by consent, however, the absence of a record makes the problem of determining the nature of the previous cause of action far more difficult than it is in the case of a litigated decree. The typical generality of antitrust complaints, often framed with only a very limited knowledge of the facts, makes them a very unreliable guide to the true cause of action. Indeed, in many instances, until discovery and pretrial proceedings have reached a fairly advanced stage, not even the plaintiff is prepared to state the precise cause of action involved. 
the consent settlement program which over recent years has accounted for more than three-quarters of all antitrust cases brought by the Department of Justice. ${ }^{20}$ Nor is it very likely that one enforcement agency will immediately take up its cudgels to assail what another agency has seen fit to accept.

At the same time, many factors can affect the permanence of the peace which the consent judgment initially produces. Changes in the national political administration and consequent changes in the policy-making personnel of enforcement agencies may well produce a re-examination of action taken in the past. The critical attention of Congress, or, more particularly, of prominent members of investigating committees, can also catalyze a shift of position within the agency. Even such factors as the presence of particularly zealous staff members, some of whom may have disagreed with the original decision, the prominence of the defendants or of the practices excluded from the settlement, the extent and nature of the publicity which the decree, its operation (or its later investigation) arouses-all these can play a role in the determination of whether, at some subsequent date, new action will be taken.

In point of fact, only in a few instances has the Government actually moved through the medium of a new proceeding to challenge the results of a bargain made in an earlier, unlitigated consent decree. ${ }^{50}$ Only two of these instances have produced reported decisions in which the effect of the prior decree was considered-the Aluminum case, in which some twenty-seven years had elapsed between the proceedings, and the $R C A$ case ${ }^{51}$ in which twenty years had intervened. Instead, the record of reported decisions indicates that the Government, when it has sought to recant its earlier bargains, has moved more forthrightly to modify the earlier decree or to have it set aside.

49. Atr'y Gen. Nat'i Comm. Antrutrust Rep. 360 (1955) ; Senate Select Committee on Small Business, The Role of Private Antitrust Enforcement in Protecting Small Business-1958, S. REP. No. 1855, 85th Cong., 2d Sess. 4 (1958).

50. There have been a number of other situations in which a prior consent decree has been pleaded in a subsequent proceeding as an affirmative defense in the nature of res judicata. See, e.g., the answer of Standard Oil Company (New Jersey) in United States v. Standard Oil Co., Civil No. 86-27, S.D.N.Y., April 21, 1953, and the defendants' answer in United States v. Western Elec. Co., Civil No. 17-49, D.N.J., Jan. 14, 1949. The latter pleading is reproduced in Hearings Before the Antitrust Subcommittee (S $S_{i b-}$ committce No. 5) of the House Committee on the Judiciary, 85th Cong., 2d Sess., ser. 9, pt. 2, at 1799 (1958).

51. The second civil proceeding, begun in 1954, was itself terminated by consent decree in 1958. United States v. Radio Corp. of America, 1958 Trade Cas. 74559 (S.D. N.Y.). It was preceded by a grand jury investigation in 1952, during the course of which ROA moved to quash the subpoena addressed to it on the ground that the matters sought to be investigated were barred from further civil or criminal proceedings by RCA's 1932 consent decree. The court declined to quash the subpoena, ruling that whatever might be the merit of the plea of bar, it was prematurely raised since the indictment had not yet been handed down. Application of Radio Corp. of America, 13 F.R.D. $167,169,170$ (S.D.N.Y. 1952). 


\section{Negotiating the Umbrella}

It seems clear from the more than occasional appearance in consent decrees of provisions designed to preserve to the Government some opportunity to proceed anew, as well as from statements like those of Mr. Kramer before the Celler subcommittee, ${ }^{52}$ that the possibility of being barred from further proceedings is a matter of some importance to the Attorney General and his staff in negotiating a consent decree. Particularly must this be the case when they conclude that, for one reason or another, the tactical situation indicates a settlement for only a fraction of the relief requested in the complaint. Without question, also, defendants in determining to accept a consent judgment place some reliance upon whatever promise the decree holds as a bar to further government proceedings. In both cases, however, weight is being attached to legal consequences which are at best uncertain, concerning which the parties may not agree, and upon which each may place a different value. Might it not be advisable in these circumstances for the parties, in their negotiations, to discuss and, if possible, to agree upon the scope of the protective umbrella?

Certainly an entirely legitimate object of consent decree negotiation is to achieve a permanent bargain disposing of all possibilities of future litigation over the same matter. Complete protection may well be impossible because of the effect of the passage of time and the fluidity of business conduct in creating new causes of action. The degree of protection attainable can, however, be substantially increased by an appropriate specification of the cause or causes of action to be disposed of by entry of the proposed consent decree. ${ }^{53}$ To accomplish such specificity, the charges of the complaint itself, as well as the terms of the decree, might fairly be made a subject of negotiation. This, of course, could more readily be done when consent-decree negotiations antedate the filing of the complaint. ${ }^{54}$ If, however, the complaint has already been filed. its amendment pursuant to the negotiations would not be impossible. Counsel might also do well to consider the practical value of including in the terms of the decree express provisions which declare particular activities or relationships to be outside the decree's prohibitions ${ }^{55}$ or which recite the extent to which the decree is intended to operate as a limitation upon proof in a subsequent proceeding. ${ }^{56}$

52. See note 1 supra.

53. Such a specification, for example, might effectively limit the opportunities of government counsel to bring a second proceeding of the type described in the text accompanying note 33 supra.

54. AtT'y Gen. Nat'l Comar. Antitrust Rep. 360 (1955).

55. If the policy expressed in the National Container press release of 1940 , note 31 supra, is still adhered to by the Department of Justice, and if that policy is acted upon, the value of the type provision described would probably be limited to defining with greater precision the scope of the decree's injunctive proscriptions.

56. As suggested in the text accompanying note 30 supra, a consent decree may have important effects in this respect, which it may be in the interests of the parties to control. Whether or not a definition of the intended evidentiary effects would be deemed 
Whatever the difficulties of foreclosing subsequent proceedings by the Government, there would appear to be little difficulty, if any, in specifying within the terms of a consent decree the areas in which later moves, either by the Government or by the defendants, are not foreclosed. Reference has already been made to the variety of provisions, appearing with increasing frequency in consent decrees, designed to clarify the extent to which future modifications or new proceedings are intended to be permitted. ${ }^{57}$ Such provisions, perhaps together with a general stipulation that the relief awarded in the decree is to endure only for a fixed period of years, would appear to constitute an effective means of placing definite limitations upon the bars, both legal and practical, which may otherwise stem from a consent decree.

Whether the parties to a particular negotiation wish to strengthen or to limit the protective umbrella, they are more apt to reach a mutually satisfactory agreement about the substantive provisions of the decree if they can accurately assess the permanency of the proposed bargain. The government negotiator who is precluded from further relief, or who thinks he may be, will probably drive a harder bargain on substantive relief than he would if, by specific provisions, he explicitly retained some freedom of action. The defendant who can thereby achieve a less onerous judgment may find it advantageous to accept an umbrella expressly limited in scope, particularly if he is aware of the umbrella's already circumscribed and uncertain protection. In many instances, the inclusion of a fixed term for the duration of a decree may be regarded as salutory by both sides-placing a definite limit both upon impediments to future government action and upon the period during which injunctive provisions, which may prove more burdensome than anticipated, must be endured by the defendant.

The subject of defining the decree's future operation may prove to be one upon which agreement cannot be reached. The desirability of raising the problem during negotiations will, of course, vary from case to case. Nevertheless, counsel for both sides would be wise to consider whether, in the circumstances of the particular proceeding, their clients' interests are better served by the perpetuation of uncertainty or by defining the umbrella's protective attributes.

controlling, such special provisions would, at least, be influential in the trial court's determination of what limits it should place upon the proof of matters antedating the decree.

57. See notes 22,32 supra. Although such clauses have been used with increasing frequency in consent decrees, the Department of Justice has apparently not sought an actual modification under this kind of provision since its unsuccessful experience in the Interitational Harvester case (274 U.S. 693) in 1923. See note 22 and the text accompanying note 9 supra. One former high-ranking member of the Antitrust Division's staff has expressed a dim view of their value to the Government in consent decrees, as distinguished from decrees entered after litigation. Kramer, supra note 30, at 1061. In view of this limited experience and the development of clauses far more explicit than that involved in Harvester, it would hardly seem that such pessimism is justified. 


\section{THE YALE LAW JOURNAL}

\begin{tabular}{lll}
\hline VolUMe 68 & JUNE 1959 & NUMBer 7 \\
\hline
\end{tabular}

\author{
Mitchel J. Ezer \\ BURT W. GRIFTIN \\ Jerold H. Israed \\ MrCHaEU J. NASSAU \\ AlaN L. WURTZEL \\ Note and Comment \\ Editors

\section{SYDNEY M. CONE, III} \\ Editor-in-Chief
}

\begin{abstract}
Matthew T. Adams
David Albenda

Alan Appelbaum

ROBERT L. BARD

Arthur J. Berk

Norman A. Bikales

Benjamin W. Boley

Richard A. BRADY

Peter D. Caldwelt.

James M. Edwards

EIIEZER Ereut

Davto R. Evans

J. EDWARD Fowler

Thomas N. Frohock

David GoLdBERG
\end{abstract}

Stuart B. Goldaman

RICHARD S. HARRISON

Netl S. Hecht

REUBEN L. HenLUNd

JacoB W. Heller

BENJAMIN T. Hopkins, II

JaAres M. Johinstone

WilliaM A. Kass

N. Herscher Koblenz

EUGENE I. LAMBERT

J. D. LAMBERT

IRUING I. LESNICK

JoHN C. MCGuire

Frederick W. MCNABb, JR

STEPHEN MANN

Donald G. Marshall
Robert J. Engelman

JOHN K. MCNULTY

Article and Book

Review Editors

T. Cecil Wray, Jr.

Mantaging Editor

Bruce Montgonery

Samuel Myers

J. Alexander Onderdonk

Alan D. Pekelner

Charlas J. Prentiss

Herbert Schreiber

BarRy SidMaN

Richard LAuder SutTon

Colin C. TaIt

JoHN W. VANDOREN

GILBERT PAUL Verbit

HERBERT S. WANDER

DONALD P. WeFER

Patricia W. Weingerg

ROBERT L. WeINBerg

Marie McMahon

Business Secretary

\section{CONTRIBUTORS TO THIS ISSUE}

Helen Srlving. Dr. Pol. Sci., Dr. Jur., University of Vienna; LL.B., Columbia University. Member of the New York Bar. Attorney, U.S. Department of Justice, 194S-1953; Research Associate, Harvard Law School, 1954-1956; Professor of Law, University of Puerto Rico, since 1956. Visiting Lecturer and Senior Fellow, Yale Law School, 1958-1959.

Seth M. Dabney. A.B. 1939, College of the City of New York; LL.B. 1942, Columbia University. Member of the New York Bar. Member, firm of Dorr, Hand, Whittaker \& Watson, New York City. 